IRA-International Journal of Education \& Multidisciplinary Studies

ISSN 2455-2526; Vol.04, Issue 02 (2016)

Pg. no. 300-308

Institute of Research Advances

http://research-advances.org/index.php/IJEMS

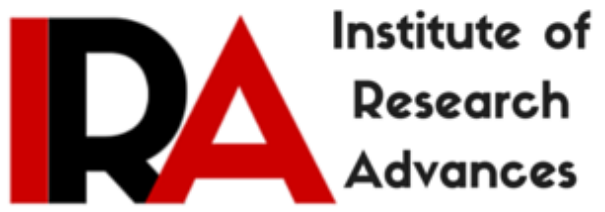

\title{
Enrolment pattern and Profile of Scheduled Caste Girl Students
}

\author{
${ }^{1}$ Beena Yadav, ${ }^{2}$ Shailja Kumari, ${ }^{3}$ Rita Goel and ${ }^{4}$ Manju Dahiya \\ 1,2,3,4 Department of EECM, CCSHAU, \\ Hisar, Haryana, India.
}

Type of Review: Peer Reviewed

DOI: http://dx.doi.org/10.21013/jems.v4.n2.p8

\section{How to cite this paper:}

Yadav, B., Kumari, S., Goel, R., \& Dahiya, M. (2016). Enrolment pattern and Profile of Scheduled Caste Girl Students. IRA International Journal of Education and Multidisciplinary Studies (ISSN 2455-2526), 4(2), 300-308.

doi:http://dx.doi.org/10.21013/jems.v4.n2.p8

(C) Institute of Research Advances

\section{(cc) EY-NC}

This work is licensed under a Creative Commons Attribution-Non Commercial 4.0 International License subject to proper citation to the publication source of the work.

Disclaimer: The scholarly papers as reviewed and published by the Institute of Research Advances (IRA) are the views and opinions of their respective authors and are not the views or opinions of the IRA. The IRA disclaims of any harm or loss caused due to the published content to any party. 


\section{ABSTRACT}

Half of the scheduled caste (SC) girl students were in the age group of 16-18 years followed by 33.0 per cent who were above 18 years of age and the age of remaining 17.0 per cent students was between 13-15 years. Maximum number of students were Haijans (34.0\%) followed by dhanak (27.0\%), balmiki (13.0\%), odd (11.0\%) and khatik (10.0\%); and majbhi sikh \& bajigar caste respondents were less than five percent (3.0\% and $2.0 \%$, respectively). Majority of them were from joint families (78.0 \%) with family size between 6-8 members (71.0\%) and aspired to be graduate (52.0\%) and be in teaching profession (37\%). Average number of siblings of the respondents was 2.48 wherein girls outnumbered boys. Illiteracy rate among their female sibling (6.9\%) was more than two times higher than male siblings (2.8\%). Their mothers were home makers (48.0\%) and fathers were labour (53.0\%) in maximum number of cases. Majority (69.0\%) of the SC girl students were from landless families.

Key words: Education, SC girls, enrolment, aspiration, sibling, parents

\section{INTRODUCTION}

Education is one of the most important dimension and potent tool of human resource development and plays a key role in sustainable social and economic development of any society. Education promotes the holistic development of an individual as it improves quality of life, promotes health, expands access to paid employment and facilitates social and political participation. It is widely accepted that investing in girls' education has important externalities for improving general social welfare, leading them to marry later and have fewer and healthier children, thereby reducing both maternal and infant morbidity and mortality rates. Promotion of girls' education is one of the cornerstones of national educational policy and a holistic vision for the education of women and girls has been adopted. Various centrally sponsored schemes have been launched which had a direct and distinct bearing on promoting education for girls. However, the state of the conditions of girls, especially from scheduled castes (SC) on the educational indicators reflects that still there is literacy gap of more than 14 per cent in case of scheduled castes an d 22 per cent in case of scheduled tribes in relation to other castes. The dropout rate is also on the higher side among the children of SCs/STs . (Singh, 2009). In spite of so many campaigns launched by the Government of India, which provide free education, majority of the SC girl do not received separate reading room at home (80\%), 52.5 $\%$ girl did not have the proper study materials and stationeries which are needed for fair study, $97.5 \%$ girls have to engage in household duties ( Sonowal, 2013). Inequalities in access to secondary education are especially prominent for girls from low-income and impoverished families (UNESCO, 2012)

To cater to this felt need, several incentive schemes for children have been implemented by the government of Haryana. The census report, 2011, though indicated upward trends in female literacy but the position of women in terms of literacy level still remains a cause of concern. This gulf is wider among the women belonging to schedule caste and backward classes. The enrolment and retention of girls in schools is an outcome of interplay of various factors. like opportunity cost of sending girl to school, number and age of younger siblings, mothers' education, socio economic status, herd size, health of parents, village development index, distance of school etc. Parental motivation and education, followed by economic status of the household, were reported the key factors for continuance of girls in schools. (Nayar, 1999). Parental motivation is highly significant to the probability of a girl being in school. Maternal education was reported to have a large positive effect on a daughter's probability of completing primary school (Dreze et al., 2000). It was therefore considered imperative to obtain information from all possible angles about SC girls with the following objectives.

- To assess the class - wise enrolment of Scheduled Caste girl students

- To explore the personal, sibling and parents related information of SC girl students 


\section{Methodology:}

The study was conducted in purposively selected Hisar and Fatehabad districts of Haryana state as these districts have female literacy rates (62.3\% and 59.3\%, respectively) below the state average (66.8\%). One block i.e. Hisar-II block from Hisar district and Fatehabad block from Fatehabad block were selected randomly. Total four Senior Secondary Schools i.e. two from each block were selected randomly. Due to implementation of Right to Education Act, the school principals showed inability in disclosing the information; hence the names of schools are kept anonymous. The data about enrolment pattern was collected by consulting the class wise school records, however for collecting information about profile related variables proportionate sample of $100 \mathrm{SC}$ girls ( 25 from each of the selected school) enrolled in classes 8-12 was drawn. The interview schedule for the present investigation was developed in accordance with the objectives of the study and data were collected personally by the investigator from selected girls.

\section{Results and discussion}

\section{Class wise enrolment of Scheduled caste girls}

The enrolment pattern of SC girls indicated that the enrolment percentage of SC girls irrespective of class raged between 10.4 to $38.5 \%$ in the selected four schools. The enrolment percentage of SC girls in the total sample was $26.3 \%$.There was decline in the enrolment percentage of SC girls after tenth class in three out of four schools (School numbers I, II , IV), however, increasing trend in enrolment after matriculation was observed in school number III only. The data further indicated that the enrolment percentage of SC girls in the school number I which was girls' school was maximum in all the classes in comparison to rest three schools which were co educational. This trend underlines the importance of girls' schools in rural areas for educational upliftment of SC girls.

Table 1. Class Wise Enrolment of Scheduled Caste Girl Students

\begin{tabular}{|c|c|c|c|c|c|c|}
\hline \multirow[t]{2}{*}{ School } & \multicolumn{5}{|c|}{ Class } & \multirow[t]{2}{*}{ Total } \\
\hline & $8^{\text {th }}$ & $9^{\text {th }}$ & $10^{\text {th }}$ & $11^{\text {th }}$ & $12^{\text {th }}$ & \\
\hline \multicolumn{7}{|l|}{ School I } \\
\hline Total students & 131 & 173 & 124 & 350 & 396 & 1174 \\
\hline SC girls (\%) & $80(61.0)$ & $76(43.9)$ & $61(49.1)$ & $113(32.2)$ & $123(31.0)$ & $453(38.5)$ \\
\hline \multicolumn{7}{|l|}{ School II } \\
\hline Total students & 47 & 66 & 57 & 78 & 96 & 344 \\
\hline SC girls $(\%)$ & $06(12.7)$ & $11(16.6)$ & $12(21.0)$ & $13(16.6)$ & $12(12.5)$ & $54(15.6)$ \\
\hline \multicolumn{7}{|l|}{ School III } \\
\hline Total students & 65 & 80 & 73 & 69 & 55 & 342 \\
\hline SC girls (\%) & $12(18.4)$ & $12(15.0)$ & $07(9.5)$ & $09(13.4)$ & $07(12.7)$ & $47(13.7)$ \\
\hline \multicolumn{7}{|l|}{ School IV } \\
\hline Total students & 54 & 92 & 74 & 87 & 96 & 403 \\
\hline SC girls (\%) & $07(12.9)$ & $13(14.1)$ & $08(10.8)$ & $07(8.0)$ & $07(7.2)$ & $42(10.4)$ \\
\hline Grand total & 297 & 411 & 328 & 584 & 643 & 2263 \\
\hline SC girls (\%) & $\begin{array}{r}105 \\
(35.3)\end{array}$ & $112(27.2)$ & $88(26.8)$ & $142(24.3)$ & $149(23.1)$ & $596(26.3)$ \\
\hline
\end{tabular}




\section{Profile of the students:}

It was reported that half of the students were in the age group of 16-18 years followed by 33.0 per cent who were above 18 years age and the age of remaining 17.0 per cent students was between 13-15 years. As far as caste of the respondents is concerned, it is obvious that all of them were from Scheduled caste (SC) as the title of the research study suggests, however, it was considered imperative to have information regarding distribution of the students under different castes within the SC category itself. It was observed that the selected students belonged to seven SC castes with maximum of them being Haijans (34.0\%) followed by dhanak (27.0\%), balmiki (13.0\%), odd (11.0\%) and khatik (10.0\%) and majbhi sikh \& bajigar caste respondents were less than five percent (3.0\% and $2.0 \%$, respectively). The distribution of selected students under various Scheduled caste (SC) categories showed Harijans as the most prominent caste. This shows that the Harijans caste parents had higher inclination to educate their girls in comparison to other castes. The other reason might be due the existence of more number of Harijans families in the selected villages.

Majority of them were from joint families $(78.0 \%)$ and remaining $(22.0 \%)$ were from nuclear families. As far as family size of the respondent is concerned, it was between 6-8 members in majority (71.0\%) of the cases followed by 17.0 percent families with members between 3-5 members and 12.0 per cent had more than 8 members in their family.

Table 1: Profile of Scheduled Caste Girl Students $(n=100)$

\begin{tabular}{|c|c|c|c|c|c|c|c|}
\hline & \multicolumn{5}{|c|}{ Class } & \multirow[t]{2}{*}{ Total } & \multirow[t]{2}{*}{$\%$ age } \\
\hline & $8^{\text {th }}$ & $9^{\text {th }}$ & $10^{\text {th }}$ & $11^{\text {th }}$ & $12^{\text {th }}$ & & \\
\hline \multicolumn{8}{|l|}{ Age } \\
\hline $13-15$ years & 14 & 3 & 0 & 0 & 0 & 17 & 17.0 \\
\hline $16-18$ years & 4 & 20 & 17 & 4 & 5 & 50 & 50.0 \\
\hline Above 18 years & 0 & 0 & 0 & 17 & 16 & 33 & 33.0 \\
\hline \multicolumn{8}{|l|}{ Caste } \\
\hline Harijan & 10 & 9 & 4 & 6 & 5 & 34 & 34.0 \\
\hline Dhanak & 2 & 7 & 7 & 4 & 7 & 27 & 27.0 \\
\hline Balmiki & 3 & 3 & 1 & 2 & 4 & 13 & 13.0 \\
\hline Odd & 2 & 1 & 3 & 3 & 2 & 11 & 11.0 \\
\hline Khatik & 1 & 2 & 1 & 4 & 2 & 10 & 10.0 \\
\hline Majhbi Sikh & 0 & 0 & 0 & 2 & 1 & 3 & 3.0 \\
\hline Bajigar & 0 & 1 & 1 & 0 & 0 & 2 & 2.0 \\
\hline \multicolumn{8}{|l|}{ Type of family } \\
\hline Nuclear & 5 & 4 & 3 & 9 & 1 & 22 & 22.0 \\
\hline Joint & 14 & 18 & 16 & 17 & 13 & 78 & 78.0 \\
\hline \multicolumn{8}{|l|}{ Size of family } \\
\hline $3-5$ members & 4 & 3 & 6 & 2 & 2 & 17 & 17.0 \\
\hline $6-8$ members & 11 & 13 & 12 & 18 & 17 & 71 & 71.0 \\
\hline More than 8 members & 3 & 2 & 2 & 1 & 4 & 12 & 12.0 \\
\hline
\end{tabular}




\section{Sibling Related Information of Scheduled Caste Girl Students:}

The data in Table indicate that the total number of siblings of selected SC girl students were 248 with an average of 2.48. This indicated that every selected girl had either two or three siblings on an average. Sex wise sibling distribution indicated that girls outnumbered boys as $58.0 \%$ of siblings were girls and remaining $42.0 \%$ were boys. Poor sex ratio is often blamed on poor socio economic status families but this does not seem hold true in the present study. It was a positive trend to observe in the present study the percentage of girls $(58.0 \%)$ was more than the boys $(42.0 \%)$. However, the reasons for such observations have far implications. Female feticide is comparatively less prevalent among under privileged or economically weaker section due to two reasons viz; lack of concern about family planning and inability to pay high fees of sex determination tests

The age-wise distribution of sibling was done on the basis of schooling age at primary, middle, secondary or senior secondary level. The data indicated that maximum number of siblings were above 18 years of age (36.6\%) followed by $20.0 \%$ in the age group of less than 11 years and $19.3 \%$ were under 11 14 years age group.

Table 2 Siblings Related Information of Scheduled Caste Girl Students

\begin{tabular}{|l|c|c|c|}
\hline $\begin{array}{l}\text { Number and sex of } \\
\text { siblings }\end{array}$ & $\begin{array}{c}\text { Boys 104 } \\
(42.0 \%)\end{array}$ & $\begin{array}{c}\text { Girls } \\
144(58.0 \%)\end{array}$ & $\begin{array}{c}\text { Total } \\
248\end{array}$ \\
\hline Age of siblings & \multicolumn{3}{|l|}{} \\
\hline Below 11 Yrs & $23(22.1)$ & $26(18.0)$ & $49(20.0)$ \\
\hline $11-14$ Year & $18(17.3)$ & $30(20.0)$ & $48(19.3)$ \\
\hline $14-16$ year & $07(6.7)$ & $16(11.1)$ & $23(9.3)$ \\
\hline $16-18$ year & $19(18.2)$ & $18(12.5)$ & $37(14.9)$ \\
\hline Above 18 Year & $37(35.5)$ & $54(37.5)$ & $91(36.6)$ \\
\hline Education of Siblings & \multicolumn{3}{|l|}{} \\
\hline Illiterate & $3(2.8)$ & $10(6.9)$ & $13(5.3)$ \\
\hline Primary & $19(18.2)$ & $30(20.8)$ & $49(19.7)$ \\
\hline Middle & $29(27.8)$ & $29(20.1)$ & $61(25.0)$ \\
\hline High school & $13(12.5)$ & $21(14.5)$ & $42(17.2)$ \\
\hline Senior Secondary & $27(25.9)$ & $8(5.5)$ & $11(4.5)$ \\
\hline Graduate & $3(2.8)$ & $2(1.3)$ & $4(1.6)$ \\
\hline Post Graduate & $2(1.9)$ & & \\
\hline
\end{tabular}

Educational pattern of siblings indicated that one fourth of them were educated up to middle level followed by equal number of siblings who had completed primary and Senior Secondary level schooling (19.7\% each). The percentage of sibling having high school education was $17.2 \%$. The percentages under illiterate, graduate and post graduate categories were quite less $(5.3 \%, 4.5 \%$ and $1.6 \%$ respectively).

The inter gender educational profile of siblings indicated that maximum number of boys had attained middle $(27.8 \%)$ and senior secondary educational level (25.9\%), however, educational level of maximum number of girls was middle school $(22.2 \%)$. 
The results regarding educational level of sibling of the selected SC students revealed the literacy gap among boys and girls at middle and senior secondary level wherein the boys outnumbered girls. The illiteracy rate among siblings of the students was $5.3 \%$ and majority of illiterates were above 18 years of age. Allowance and incentive based educational schemes were implemented in Haryana state eight years back (during 2005-06) and school enrolment age of all the illiterate siblings was before implementation of the educational schemes. This further suggested that the not only the selected students but all of their sibling were enrolled in the school after implementation of the educational schemes ,showing impact of these schemes on SC students enrolment.

Illiteracy rate among female sibling (6.9\%) was more than two times higher than male siblings (2.8\%). The results are in tune with the findings of Sudhakar et al. (1999), Kingdon (2002), Lewis et al. (2006) \& Herz et al. (2004) who remarked that there was a clear gender bias towards education of the male child1with sc girl lagging behind due to house hold differential treatment of children in educational expenditure.

\section{Parents Related Information of Scheduled Caste Girl Students}

Information about the profile of parents of the selected SC students as discussed below is given in table 3.The information regarding age of the parents indicated that majority of the mothers $(62.0 \%)$ as well as fathers $(67.0 \%)$ were in the age group of 39-47 years. The number of parents in remaining age categories differed, as only 4.0 percent fathers were between $30-38$ years while 24.0 percent mothers were under this age group. In upper age group i.e. above 47 years the percentage of fathers $(29.0 \%)$ was more than the mothers $(14.0 \%)$

Mothers of the maximum number SC girl students were home makers (48.0\%) followed by labour $(46.0 \%)$ and self employed + labourer $(6.0 \%)$. The fathers of the maximum number of the respondents were also labour (53.0\%), followed by those who were doing private jobs (29.0\%) and self employed as well as labour work (18.0\%). There had been remarkable high proportion of Scheduled Caste population in primary activity. It is observed that more Scheduled Caste population engaged in primary activity as agriculturallaboursThis has due to most of people did not having his own land. Thus, people works on landholders land for wages in money.

More than half of the mothers of the respondents were illiterate $(57.0 \%)$ followed by those who were educated upto primary $(19.0 \%)$ middle school (18.0\%), senior secondary $(5.0 \%)$ and high school (1.0\%) the data clearly indicated that the percentage of mothers went on declining as the educational level increased except between high school and senior secondary level.

In case of education of father it was clearly seen that their number was less than mothers under illiterate category and more under high school and senior secondary level. Fathers of maximum numbers of students were middle pass $(27.0 \%)$ followed by those completing high school $(22.0 \%)$ primary schooling (16.0\%) and senior secondary (14.90). The illiterate fathers were $21.0 \%$ against 57.0 percent mothers. It means illiteracy rate was more than two and a half times among mothers than fathers of the selected SC girl students. Majority of the families were landless (69.0\%) and remaining 31.0 percent had landholding maximum between half to two acres only. Gap in education of mothers and father of selected SC girl students was observed as $57.0 \%$ mothers were illiterate against $21.0 \%$ fathers .The observations are in consonance with the given by Hazra (2009) who confirmed that the gender gap in educational involvement though reduced over the years, but in India, it is still a matter of great concern. One of the discrimination that girls and women are facing in India is the fact that they are not able to enjoy the right to education. More than half of the adult illiterates $(63 \%)$ are women and nearly $2 / 5^{\text {th }}$ girls enrolled in primary schools are dropout before graduate. 
Table 3. Parents Related Information of Scheduled Caste Girl Students

\begin{tabular}{|c|c|c|}
\hline Variable & $\begin{array}{c}\text { Mother }\left(\mathrm{n}_{1}=100\right) \\
\text { Frequency }(\%)\end{array}$ & $\begin{array}{c}\text { Father }\left(\mathbf{n}_{2}=100\right) \\
\text { Frequency }(\%)\end{array}$ \\
\hline \multicolumn{3}{|l|}{ Age } \\
\hline $30-38$ years & $24(24.0)$ & $04(4.0)$ \\
\hline 39-47 years & $62(62.0)$ & $67(67.0)$ \\
\hline Above 47 years & $14(14.0)$ & $29(29.0)$ \\
\hline \multicolumn{3}{|l|}{ Education } \\
\hline Illitrate & $57(57.0)$ & $21(21.0)$ \\
\hline Primary & $19(19.0)$ & $16(16.0)$ \\
\hline Middle & $18(18.0)$ & $27(27.0)$ \\
\hline High school & $1(1.0)$ & $22(22.0)$ \\
\hline Senior Secondary & $5(5.0)$ & $14(14.0)$ \\
\hline \multicolumn{3}{|l|}{ Occupation } \\
\hline Housewife & $48(48.0)$ & -- \\
\hline Labour & $46(46.0)$ & $53(53.0)$ \\
\hline Self Employed +labour & $6(6.0)$ & $18(18.0)$ \\
\hline Private Job & -- & $29(29.0)$ \\
\hline \multicolumn{3}{|l|}{ Family Income } \\
\hline Below Rs.5000 & $13(13.0)$ & $13(13.0)$ \\
\hline Rs. 5000- Rs. 8000 & $24(24.0)$ & $24(24.0)$ \\
\hline Above Rs. 8000 & $63(63.0)$ & $63(63.0)$ \\
\hline \multicolumn{3}{|l|}{ Land holding } \\
\hline Landless & $69(69.0)$ & $69(69.0)$ \\
\hline Upto 2 Acres & $31(31.0)$ & $31(31.0)$ \\
\hline
\end{tabular}

\section{Educational and professional aspirations of the SC girl students:}

It was indicated that slightly more than half of the respondent $(52.0 \%)$ aspired to be graduate followed by those who aspired to be educated upto post graduate (15\%) and senior secondary $(13.0 \%)$ level. The aspiration of 11.0 percent was to get technical degrees ( ITI, JBT, B. Tech.etc.) and 9.0 percent wanted to do post doctorate.

Teaching profession was most aspired by the selected SC girl students as maximum number of them wanted to be teacher $(37.0 \%)$ followed by those who aspired to become doctor $(22.0 \%)$ and police officer $(19.0 \%)$ and bank official (9.0\%), while $5.0 \%$ of the SC girls had no specific professional aspirations, however, they wanted to be employed into any government job. Professions like advocate, artist, model $(4.0 \%)$ and engineering (3.0\%) were also aspired by these girls, though the percentage comparatively less.

The selected SC girls students had high educational aspiration and more than half of them i.e 52.0\% aspired to attain graduate degree and Ph.D was the highest educational level aspired by the students. Professional aspiration indicated that teaching profession was most preferred by them. The SC girl students aspired for high profile jobs like medical, policing, banking, engineering etc. The results were quite motivating as were in spite of being from marginalized, underprivileged and economically weaker sections of the society these girl students had high educational and professional aspirations. The provision of cash allowances and incentives like books, cycles and uniform might have inculcated a sense of confidence among these students. The selected girls themselves admitted during data collection they could not even think of completing primary schooling in the absence of educational allowances and 
incentives. Kaul (2001) also observed that even in Government run schools parents have to spend on stationery, transport, school bags and uniforms. Of the 291 girls interviewed from lower income group, $55.67 \%$ stated that they would not be able to complete school, due to economic compulsions. Thus the high educational and professional aspirations reported in the study are attributed to the impact of educational schemes.

School related variables: School is considered to play a dominant role in not only shaping the educational activities but also wholesome personality development of the student. Some critical variables which are linked to the educational schemes and also act as determinant of retention of students especially girls in the school were included in the study

Distance of school from home: This variable was included to explore the number of students who were entitled to avail cycle facility as the eligibility criteria for provision of cycles is that the distance of school from home/ place of residence should be between 2-8kilometers. The information was sought under two categories i.e. $2-8 \mathrm{kms}$ and above $8 \mathrm{kms}$.It was reported by very high majority of the respondent (94.0\%) that distance between their home and school was between $2-8 \mathrm{Kms}$ and remaining 6.0 percent reported more than $8 \mathrm{Kms}$ distance.

Mode of conveyance to school: Majority of the respondents reported that they go to school on foot (74.0\%) followed by 16.0 percent who reported use of public transport like auto rickshaw/bus and only 10.0 percent of the respondents were found to make use of cycle to reach their schools. Quit high majority of the students (94\%) had to travel 2 to $8 \mathrm{~km}$ from their place of residence to reach school which is indicative of the fact that these 94.0 percent children were entitled to avail the provision of cycle under cycle scheme. Tinnari (2002) also highlighted in their study that the girls had to travel between half to more than five kilometer to reach school. Though $94.0 \%$ students were entitled to get cycle but only $10.0 \%$ were observed to use the cycle to go to school with majority of the girls under study going to school on foot $(74.0 \%)$ indicating gap in utilization of incentives provided under educational schemes.

\section{References:}

1. Hazra, Anupam (2009).Gender disparity in education. Yojana, 53, Ministry of Information and Broadcasting, Govt. of India, New Delhi.

2. Herz, Barbara and Gene Sperling (2004). What Works In Girls' Education: Evidence and Policies from the Developing World. New York: Council on Foreign Relations, Inc.

3. Kaul, Rekha (2001). Accessing primary education - going beyond the classroom. Economic and Political Weekly, 36(2): 155-62

4. Kingdon, Geeta Gandhi (2002). The Gender Gap in Educational Attainment in India. Journal of Development Studies, 39(2): 25-53.

5. Lewis, Maureen A. and Marlaine E. Lockheed (2006). Inexcusable Absence: Why 60 Million Girls Still Aren't in School and What to Do about It. Washington: Center for Global Development.

6. Singh, D (2009) Development of Scheduled Castes in India- A review Journal of Rural Development, 28 (4): 531-32.

7. Sudhakar, C., Umamohan and Sugunakumari, R. (1999). Universalization of girls' education: community participation. Journal of Education and Social Change, 12(4): $14-27$

8. Sonowal ,M.K (2013) Impact of Education in Women Empowerment: A Case Study of SC and ST women of Sonitpur District, Assam. BASIC, APPLIED \& SOCIAL SCIENCES, VOLUME III : 32 http://www.caesjournals.org/spluploads/IJBASS-2013008.pdf IJCAES SPECIAL ISSUE ON 
9. Tinnari (2002). Impact study of education incentives to school going girls in Haryana. Third World Centre for Comparative Studies, New Delhi. TINNARI. 102 p.

10. UNESCO.2012 From access to equality empowering women and girls through literacy and secondary education. The United Nations Educational, 7, Place de Fontenoy, 75352 Paris 07 SP, France : 12.

11. http://shodhganga.inflibnet.ac.in/bitstream/10603/2496/14/14_chapter\%207.pdf 